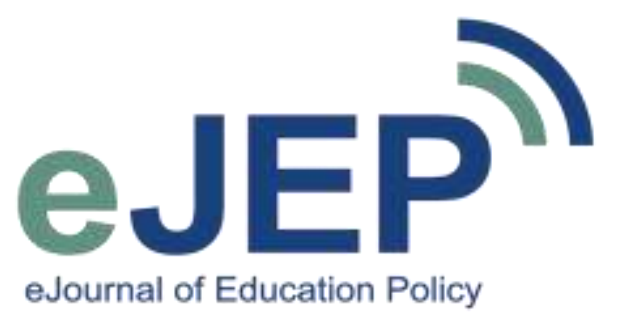

\title{
Charter School Entry, Teacher Freedom, and Student Performance
}

To cite this article: Kalulu, M., Burke, M., \& Snyder, T. (2020). Charter school entry, teacher freedom, and student performance. eJournal of Education Policy, 21(1). https://doi.org/10.37803/ejepS2004

Mavuto Kalulu, Ph.D.

Policy Analyst

Arkansas Center for Research in Economics

University of Central Arkansas

Conway, AR 72035

mkalulu@uca.edu

Morgan Burke

Honors College Student

University of Central Arkansas

Conway, AR 72035

mburke@cub.uca.edu

Thomas Snyder, Ph.D.

Associate Professor of Economics

University of Central Arkansas

Conway, AR 72035

tjsnyder@uca.edu

\begin{abstract}
Charter schools are the most popular alternative to traditional public schooling in the United States. The majority of research indicates positive effects of charter schools on student performance in traditional public schools. Most studies use the share of charter school students enrolled as a measure of the competitive pressure of charter schools. We contend that competitive pressure on traditional public schools also comes from an alternative teaching environment provided by charter schools. A teacher may be attracted to the freedom that a charter school provides, which can empower them to be innovative. These changes can spill over to traditional public schools. We empirically examine the impact this choice for teachers has on student performance in traditional public schools. We measure student performance by the percentage of $8^{\text {th }}$-grade students that attain proficiency level and above on National Assessment of Educational Progress exams. Our results indicate a positive relationship between teacher freedom in charter schools and the performance of traditional public school students.
\end{abstract}

Keywords: Charter Schools, Charter School Laws, National Assessment of Educational Progress (NAEP), School Choice 


\section{Introduction}

Charter schools provide an alternative to traditional public schooling in the United States. Nobel Prize Laureate Milton Friedman argued that competition in K - 12 education is key to improving education outcomes (Friedman \& Friedman, 1990). Competition can encourage teachers in both traditional public schools and charter schools to improve their delivery of service, otherwise they may lose students. Evidence on the competitive effect of charter schools on student performance is, however, mixed. The results range from a positive (Booker, Gilpatric, Gronberg, \& Jansen, 2008) to a negative effect (Bifulco \& Ladd, 2005). Most of the studies measure charter school competition using percentage of charter school enrollment. We expect that charter enrollment alone does not fully capture the competitive pressure traditional public schools face from charter school entry. Teachers are also choosing where to teach, and charter schools offer an alternative. One factor that teachers may consider is the additional freedom they have in charter schools, which can empower them to be innovative. By offering an alternative place of employment, charter schools put pressure on traditional public schools to retain and attract quality teachers. Does this employment competition affect student outcomes?

The main contribution of this paper is to examine the relationship between the differing state laws concerning teacher freedom in charter schools and the educational outcomes in traditional public schools. In theory, a traditional public school may react to charter-school competition by creating a better workplace for their teachers, and this may increase their effectiveness on student outcomes. Similar to competition in business, where a new nearby restaurant can force the old restaurant to improve its facilities, worker training, and ultimately improve customer service. We utilize an assessment of states' charter school laws by the Center for Education Reform to determine whether or not a state grants charter school teachers freedom to make decisions apart from the traditional public schools. Currently, forty-four states have charter schools laws. We examine the effect for school years 2008 - 2009, 2010 - 2011, $2012-2013$, and 2014-2015. The school years are selected because our outcome variable, the National Assessment of Education Progress (NAEP) exams, are conducted every other year.

Our results reveal that teacher freedom explains some of the states' differences in the percentage of students that attain proficiency level or above in both math and reading. The share of students enrolled in charter schools has a positive and significant effect on students' performance when we account for endogeneity.

The next section discusses the literature review. We then discuss the data, the empirical analysis and results, and conclude with some policy recommendations.

\section{Literature Review}

Studies on the effects of charter schools on traditional public school performance have yielded mostly positive, but mixed results. The positive effects range from modest to strong. Bohte (2004) examines the effects of charter schools on Texas public schools' performance using school-district data from 1996 to 2002. His study suggests modest overall performance gains for traditional public school students. Bohte observes a larger positive effect on low-income students enrolled in traditional public schools. A later study on Texas public schools by Booker et al. (2008) observed larger positive effects on overall performance from 1993 to 2003. They also show that the benefits mainly accrue to the disadvantaged groups and low-achieving schools. 
Buddin and Zimmer (2005) discovered modest positive results in overall performance for students in California. Yusuke Jinnai (2014) examined the effects of introducing charter schools on traditional public schools through direct and indirect impacts of grade ranges by exploiting the fact that charter schools grade ranges expanded over time. Direct impacts refer to overlapping grade ranges, and indirect impacts refer to non-overlapping grade ranges. Using North Carolina student-level panel data, Jinnai demonstrated overall positive effects of introducing charter schools. He argues that $85 \%$ of the previous studies underestimated the effects of introducing charter schools by not addressing direct and indirect impacts. Cordes (2016) discovered a similar result when examining the spillover effect of charter schools on public schools in New York City. She revealed that charter schools significantly increase overall performance in math and English language.

While Cordes (2016) observed significant positive effects for both math and English language in New York City, other studies show mixed results. An earlier study in New York City by Winters (2011) revealed a moderate positive effect of charter school penetration in New York City in reading but not in math. Contrary to Winters, Sass (2006) found a moderate increases in math scores but no significant effect on reading in North Carolina. Bifulco and Ladd (2005) discovered an insignificant effect of charter school competition on performance in North Carolina traditional public schools. However, they point out that this may be due to the limited amount of competition for the traditional public schools. Imberman (2011) concluded that charter school penetration reduces traditional public school performance in math and reading in elementary students.

Several possible reasons can explain the mixed results of the effect of charter school competition on public school performance. First, the studies use different estimation techniques. For example, both Bohte (2004) and Booker et al. (2008) study charter school impact on Texas public schools but find slightly different results, albeit both finding positive effects of charter schools. Aside from using slightly different samples, Bohte uses time-series analysis while Booker et al. (2008) uses panel-data analysis. Second, the researchers are examining outcomes in different states. The competitive effect of charter schools may be state specific and hence the different results in different states. Third, the studies use different measures of students' performance. We have seen that some studies find a significant effect in one measure but not in the other (Sass, 2006 \& Winters, 2011). Fourth, the measures of charter school competition differs across studies.

Different measures of competition can lead to different estimates of charter school impact. Some studies measure charter competition by the distance between traditional public school and the nearest charter school (Cordes, 2016), while others measure charter school competition by the percentage of students who left traditional public schools to enroll in charter schools (Winters, 2011). Our study measures competition by not only looking at the charter school enrollment, but also looking at an aspect of the charter school laws that allow charter schools to be a true alternative to traditional public schools - the freedom of teachers to operate differently from a traditional public school. The traditional public school may improve their conditions for teachers to keep them from going to a charter school, and those improvements may create better outcomes for students. 


\section{Data}

Our data is a state-level panel for school years 2008-2009, 2010-2011, 2012-2013, and 20142015. We collected our data from the National Center for Education Statistics, U.S. Census Bureau, and the Center for Education Reform (Zgainer \& Kerwin, 2015). Table 1 provides the summary statistics for all the variables used in the analysis.

Table 1: Summary Statistics

\begin{tabular}{|c|c|c|c|c|}
\hline & Mean & Std. Dev & Min & Max \\
\hline Math (\%) & 33.604 & 7.761 & 11.000 & 55.000 \\
\hline Reading $(\%)$ & 32.839 & 6.729 & 14.000 & 48.000 \\
\hline $\begin{array}{l}\text { Share of charter students } \\
(\%)\end{array}$ & 4.648 & 6.408 & 0.000 & 42.690 \\
\hline Teacher freedom & 0.745 & 0.437 & 0.000 & 1.000 \\
\hline $\begin{array}{l}\text { Limited English } \\
\text { proficiency }(\%)\end{array}$ & 6.732 & 4.116 & 1.000 & 24.000 \\
\hline $\begin{array}{l}\text { Free \& reduced price lunch } \\
(\%)\end{array}$ & 47.148 & 11.043 & 20.000 & 92.000 \\
\hline Household income & 53823.260 & 8891.984 & 36600.000 & 74551.000 \\
\hline Per pupil expenditure & 6882.215 & 2168.640 & 4070.000 & 14570.000 \\
\hline Pupil teacher ratio & 15.567 & 2.716 & 11.700 & 23.700 \\
\hline Minority (\%) & 0.392 & 0.195 & 0.060 & 0.940 \\
\hline
\end{tabular}

$\mathrm{N}=149$

Our outcome variable is student performance. We measure student performance using the National Assessment of Education Progress (NAEP) assessments. NAEP presents assessment results as the average score and the percentage of students that attain a certain achievement level. We use the later measure in our analysis for simplicity and clarity. NAEP reports the percentage of students performing at or above three achievement levels, namely basic, proficient and advanced. We use the percentage of students that achieve at or above proficient level. NAEP exams have an advantage over other measures of performance such as ACT and SAT because the same tests are administered to a representative sample of students across states unlike ACT and SAT which may suffer from a self-selection problem. NAEP exams are administered in different subjects to students in grades 4,8 , and 12 . We focus on $8^{\text {th }}$-grade reading and math exams, since $4^{\text {th }}$ grade may be a little early to test the competitive effects and $12^{\text {th }}$ grade doesn't have as much charter competition. Researchers such as Winters (2011) and Sass (2006) have shown that the impact of charter schools is subject specific.

Our main independent variables of interest are the share of charter students and teacher freedom. Our analysis is restricted to 42 states and the District of Columbia because as of 2015 eight states did not have charter schools. Previous research has used the share of charter students as a measure of competitive pressure on traditional public schools. The expectation is that the higher the percentage, the higher the competition which should in turn cause traditional public schools to improve for fear of losing students. Our main contribution is to recognize that part of the competitive pressure that traditional public schools face arise from the differences in the freedoms that charter school teachers have compared to traditional public schools. Another less trivial contribution is the instruments that we use to deal with endogeneity. 
The data on teacher freedom are obtained from the Center for Education Reform (Zgainer \& Kerwin, 2015). Teacher freedom takes the value of 1 if charters are their own legal entity and may work independently of district contract work rules and they have the option to participate in the state's retirement system, and 0 if not. Table 1 shows that 75 percent of states grant charter teachers' freedom.

Many other factors affect student outcomes. To isolate the competitive effect of charter schools on students' performance, we control for several of those factors. Our analysis controls for demographic variables, including the percentage of minority students, those on free-and-reduced lunch, and those students with limited English proficiency. The rationale for including these variables is that states with a higher percentage of disadvantaged students tend to perform worse than those that do not. We also control for classroom inputs such as student-teacher ratio and per-pupil expenditure. The expectation is that students tend to perform worse in larger classes because they get less attention than with smaller classes. We use household income to control for the socio-economic differences across the states.

\section{Empirical Analysis and Results}

\section{Regression Analysis}

Based on the nature of our data, there are three issues that have to be addressed to ensure the reliability of the estimates. First, the values of our dependent variable are restricted between 0 and 1. Thus, the usual linear regressions such as OLS are not appropriate for estimating regression parameters. Papke and Wooldridge (1996) argue that using OLS for such data cannot guarantee the estimates will lie within the unit interval. They instead propose quasi-likelihood estimation (QMLE) methods. The results of our estimations are shown in Table 2. In columns 1 and 3 we provide the coefficient estimates of using pooled QMLE. The dependent variable in column 1 is the percentage of students that score at or above proficiency in Grade 8 math while in column 3 the dependent variable is the percentage of students that score at or above proficiency in Grade 8 reading. We are interested in the average marginal effects, so we provide the average partial effects (APE) in columns 2 and 4 for math and reading, respectively. The results in columns 2 and 4 show a negative effect of the share of charter schools students in both math and reading. The coefficient for teacher freedom is positive and statistically significant for both math and reading.

Using pooled QMLE, however, ignores the panel nature of our data, which is the second issue that we have address. Hsiao (2007) states that panel data has a greater capacity to capture the complex behavior of economic players than cross-sectional and time-series data on their own. We follow Papke and Wooldridge (2008) and estimate the parameters using the Generalized Estimated Method (GEE). Columns 5 and 7 provide the coefficient effects while columns 6 and 8 provide the average partial effects. Unlike pooled QMLE estimation, the results show that the share of charter students has a negative relationship with math and no statistical relationship with reading. Teacher freedom has positive and statistical relationship with both math and reading.

The third issue we address is the possibility that the share of students in charter school is endogenous. Recall that the share of charter school is used to measure the level of competition public schools face. Poor performance is one of the reasons parents would want to enroll their 
children in alternative schools such as charter schools. In addition, states that perform poorly seem more likely to authorize alternatives to traditional public schools. Thus, there is a possibility of a two-way causation between students' performance and the share of students enrolled in charter schools.

To address the endogeneity, we follow Woodridge (2015) who recommends use of a control function method where you run a regression of the endogenous explanatory variable on all the explanatory variables and an instrumental variable for the endogenous variable. You then predict the residuals which are then included in the main model. A valid instrument must satisfy the condition that it must be highly correlated with the endogenous variable. In addition, the coefficient on the residuals must be significant, thus rejecting the null hypothesis that the explanatory variable is exogenous. In our case, we instrument the share of charter school students with two instruments. The first one is the dummy variable that takes the value of 1 if both legislative houses as well as the executive branch is controlled by republicans, and a 0 otherwise. The rationale is that republicans are more likely to advance school choice programs than democrats. The second instrumental variable is the lag of the performance which we envisage is correlated with the decision to switch to charter schools but does not affect the dependent variable because the cohort taking the exams is different from the cohort that took the exam two years earlier. In addition, the students that sit for the exam are randomly selected and there is no one school that can systematically decide to improve their NAEP score based on previous year's score. 
Table 2: Estimates for competitive effects of charter schools on students' performance

\begin{tabular}{|c|c|c|c|c|c|c|c|c|c|c|c|c|}
\hline \multirow{4}{*}{$\begin{array}{l}\text { Model: } \\
\text { Estimation method: } \\
\text { VARIABLES }\end{array}$} & \multicolumn{4}{|c|}{ Fractional probit } & \multicolumn{4}{|c|}{ Fractional probit } & \multicolumn{4}{|c|}{ Fractional probit } \\
\hline & \multicolumn{4}{|c|}{ Pooled QMLE } & \multicolumn{4}{|l|}{ GEE } & \multicolumn{4}{|c|}{ GEE (Control Function Method) } \\
\hline & \multicolumn{2}{|l|}{ Math } & \multicolumn{2}{|l|}{ Reading } & \multicolumn{2}{|l|}{ Math } & \multicolumn{2}{|l|}{ Reading } & \multicolumn{2}{|l|}{ Math } & \multicolumn{2}{|l|}{ Reading } \\
\hline & Coefficient & APE & Coefficient & APE & Coefficient & APE & Coefficient & APE & Coefficient & APE & Coefficient & APE \\
\hline & (1) & (2) & (3) & (4) & (5) & (6) & (7) & (8) & (9) & (10) & (11) & (12) \\
\hline \multirow[t]{2}{*}{ Share of charter students (\%) } & $-0.5552^{* *}$ & $-0.1991^{* * *}$ & $-0.9232^{* * *}$ & $-0.3291^{* * *}$ & $-0.5463^{* *}$ & $-0.1964^{* *}$ & -0.5795 & -0.0268 & $5.1792^{* * *}$ & $1.8751^{* * *}$ & $4.5322^{* * *}$ & $1.6288^{* * *}$ \\
\hline & $(0.2186)$ & $(0.0784)$ & $(0.1673)$ & $(0.0597)$ & $(0.2660)$ & $(0.0959)$ & $(0.3675)$ & $(0.1308)$ & $(1.2297)$ & $(0.4453)$ & $(0.7482)$ & $(0.2665)$ \\
\hline \multirow[t]{2}{*}{ Teacher freedom } & $0.0995^{* * *}$ & $0.0353^{* * *}$ & $0.1061^{* * *}$ & $0.0373^{* * *}$ & $0.0891 * *$ & $0.0317^{* *}$ & $0.0655^{*}$ & $0.0232^{*}$ & $0.0574^{*}$ & $0.0207^{*}$ & $0.0627^{* *}$ & $0.0224^{* *}$ \\
\hline & $(0.0228)$ & $(0.0080)$ & $(0.0178)$ & $(0.0062)$ & $(0.0417)$ & $(0.0148)$ & $(0.0360)$ & $(0.0126)$ & $(0.0327)$ & $(0.0117)$ & $(0.0253)$ & $(0.0090)$ \\
\hline \multirow[t]{2}{*}{ Limited English proficiency (\%) } & $0.8317^{* *}$ & $0.2983^{* *}$ & -0.0714 & -0.0254 & -0.3402 & -0.1223 & $-0.9557^{*}$ & $-0.3411^{* *}$ & $0.9284^{* *}$ & $0.3361^{* *}$ & 0.3151 & 0.1133 \\
\hline & $(0.4109)$ & $(0.1475)$ & $(0.3283)$ & $(0.1170)$ & $(0.4470)$ & $(0.1608)$ & $(0.4911)$ & $(0.1749)$ & $(0.4426)$ & $(0.1601)$ & $(0.3417)$ & $(0.1226)$ \\
\hline \multirow[t]{2}{*}{ Free \& reduced price lunch $(\%)$} & $-0.5119^{* * *}$ & $-0.1836^{* * *}$ & 0.0747 & 0.0266 & -0.0697 & -0.0251 & $0.3821^{* * *}$ & $0.1363^{* * *}$ & -0.0211 & -0.0076 & $0.5424^{* * *}$ & $0.1949^{* * *}$ \\
\hline & $(0.1503)$ & $(0.0540)$ & $(0.1285)$ & $(0.0458)$ & $(0.0831)$ & $(0.0299)$ & $(0.0874)$ & $(0.0316)$ & $(0.1139)$ & $(0.0412)$ & $(0.0955)$ & $(0.0343)$ \\
\hline \multirow[t]{2}{*}{ Household income } & $0.0128^{* * *}$ & $0.0046^{* * *}$ & $0.0122^{* * *}$ & $0.0044^{* * *}$ & $0.0172^{* * *}$ & $0.0062^{* * *}$ & $0.0175^{* * *}$ & $0.0062^{* * *}$ & $0.0195^{* * *}$ & $0.0071^{* * *}$ & $0.0192^{* * *}$ & $0.0069^{* * *}$ \\
\hline & $(0.0019)$ & $(0.0007)$ & $(0.0016)$ & $(0.0006)$ & $(0.0023)$ & $(0.0008)$ & $(0.0020)$ & $(0.0007)$ & $(0.0022)$ & $(0.0008)$ & $(0.0018)$ & $(0.0006)$ \\
\hline \multirow[t]{2}{*}{ Per pupil expenditure } & $-0.0158^{*}$ & $-0.0057^{*}$ & 0.0077 & 0.0028 & $-0.0194^{*}$ & $-0.0070^{*}$ & -0.0057 & -0.0020 & $-0.0383^{* * *}$ & $-0.0139^{* * *}$ & $-0.0144^{* *}$ & $-0.0052^{* *}$ \\
\hline & $(0.0083)$ & $(0.0030)$ & $(0.0064)$ & $(0.0023)$ & $(0.0113)$ & $(0.0041)$ & $(0.0074)$ & $(0.0026)$ & $(0.0099)$ & $(0.0036)$ & $(0.0064)$ & $(0.0023)$ \\
\hline \multirow[t]{2}{*}{ Pupil teacher ratio } & $-0.0151^{* * * *}$ & $-0.0054^{* * *}$ & -0.0004 & -0.0001 & -0.0031 & -0.0011 & $0.0168^{* *}$ & $0.0060^{* *}$ & $-0.0480^{* * *}$ & $-0.0174^{* * *}$ & $-0.0316^{* * *}$ & $-0.0114^{* * *}$ \\
\hline & $(0.0052)$ & $(0.0019)$ & $(0.0040)$ & $(0.0014)$ & $(0.0061)$ & $(0.0022)$ & $(0.0077)$ & $(0.0027)$ & $(0.0101)$ & $(0.0037)$ & $(0.0075)$ & $(0.0027)$ \\
\hline Minority (\%) & $\begin{array}{l}-0.5751^{* * * *} \\
(0.0916)\end{array}$ & $\begin{array}{l}-0.2062^{* * * *} \\
(0.0326)\end{array}$ & $\begin{array}{l}-0.6309^{* * * *} \\
(0.0741)\end{array}$ & $\begin{array}{l}-0.2249^{* * * *} \\
(0.0262)\end{array}$ & $\begin{array}{l}-0.6379^{* * *} \\
(0.1440)\end{array}$ & $\begin{array}{l}-0.2293^{* * * *} \\
(0.0510)\end{array}$ & $\begin{array}{l}-0.6415^{* * *} \\
(0.1062)\end{array}$ & $\begin{array}{l}-0.2289^{* * * *} \\
(0.0378)\end{array}$ & $\begin{array}{l}-0.9502^{* * * *} \\
(0.1152)\end{array}$ & $\begin{array}{l}-0.3440^{* * *} \\
(0.0413)\end{array}$ & $\begin{array}{l}-1.0120^{* * * *} \\
(0.0899)\end{array}$ & $\begin{array}{l}-0.3637^{* * * *} \\
(0.0318)\end{array}$ \\
\hline \multirow[t]{2}{*}{ v1h } & & & & & & & & & $-5.6748^{* * *}$ & & & \\
\hline & & & & & & & & & $(1.1555)$ & & & \\
\hline \multirow[t]{2}{*}{ v6h } & & & & & & & & & & & $-4.5879^{* * *}$ & \\
\hline & & & & & & & & & & & $(0.8560)$ & \\
\hline Wald chi2 & 310.03 & & 443.33 & & 120.6 & & 231.87 & & 192.15 & & 383.48 & \\
\hline Log pseudolikelihood & -93.63 & & -93.10 & & & & & & & & & \\
\hline $\mathrm{N}$ & 149 & 149 & 149 & 149 & 149 & 149 & 149 & 149 & 145 & 145 & 145 & 145 \\
\hline
\end{tabular}

Standard errors in parentheses $* * * \mathrm{p}<0.01, * * \mathrm{p}<0.05, * \mathrm{p}<0.1$ 


\section{Interpretation of the Results}

We believe the appropriate estimation is the GEE (Control Function Method), which incorporates all three estimation issues raised earlier. Columns 10 and 12 show the average partial effects (APE), and we see that the APE for the share of charter school students is 1.87 and 1.63 for math and reading, respectively. This means that on average a 1 percentage point difference in charter school enrollment is associated with 1.87 and 1.63 percentage-point performance difference in math and reading, respectively. Recall, however, that our model is nonlinear which means that the marginal effect of the share of charter school students is not the same at different levels of the share of charter students. APE gives the average of the marginal effects at the different values of competition in our sample. Figures 1 and 2 graph the predicted values of the percentage of students that achieve at least proficiency level in grade 8 math and grade 8 reading at different values of competition (share of charter school enrollment).

Figure 1: Predictive Margins for Charter Enrollment with 95\% Cis (Math)

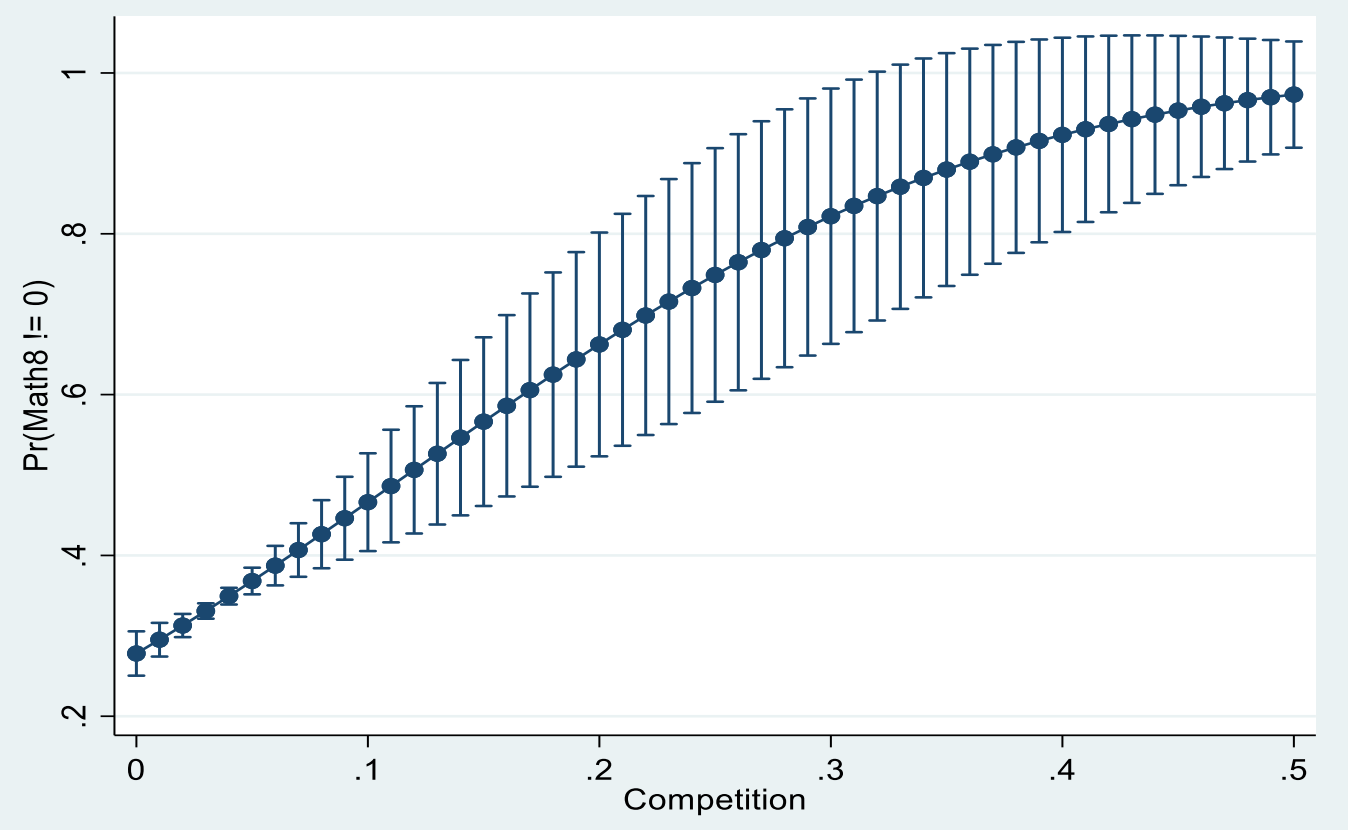


Figure 2: Predictive Margins for Charter Enrollment with 95\% Cis (Reading)

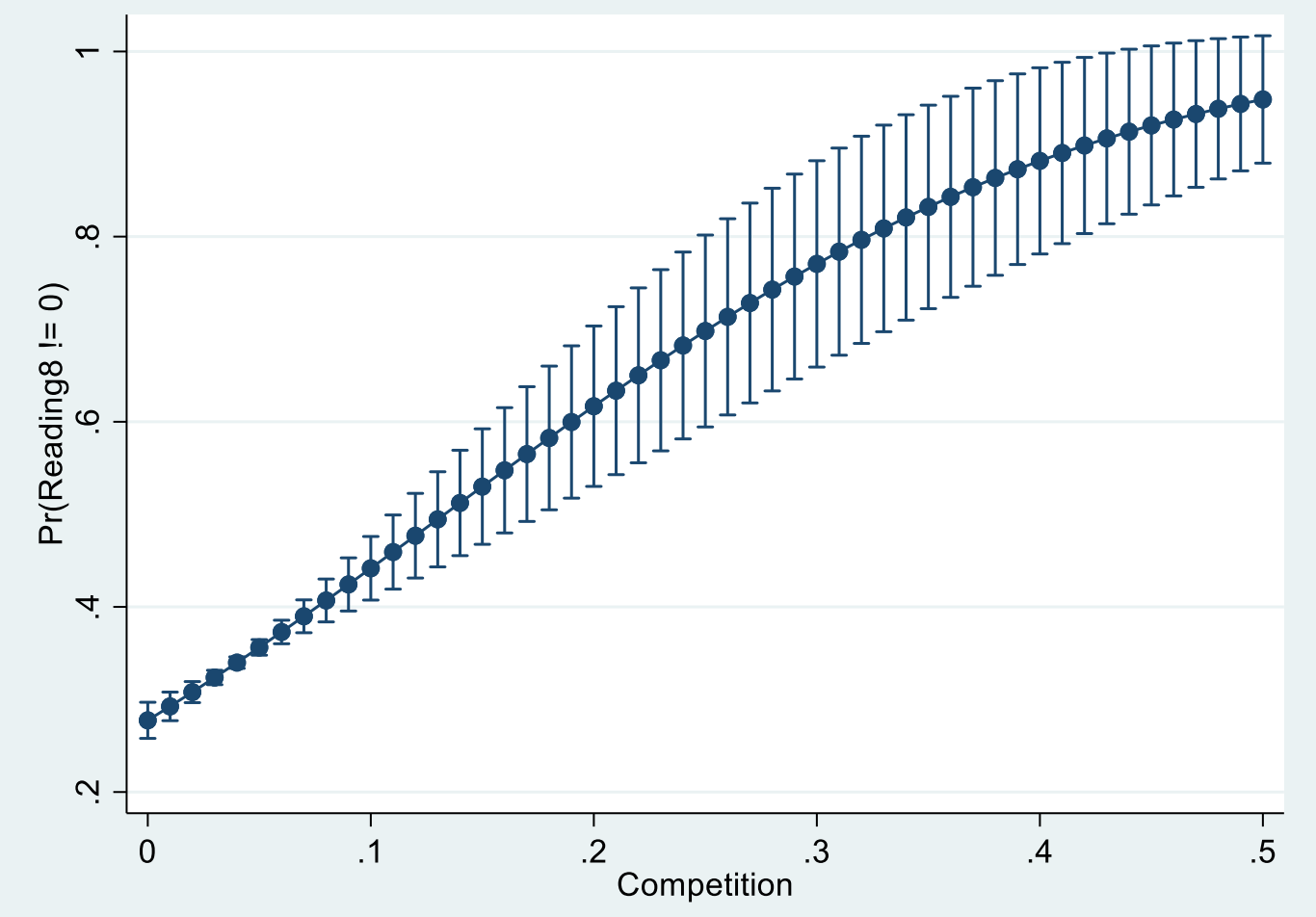

Figures 1 and 2 reveal that there is a positive relationship between the share of students enrolled in charter schools and students' performance. The slope of the graphs reveal that the effect of charter school competition increasingly higher at lower levels of competition but diminishes as the share of charter school students increases. The inflection points are at around 0.12 and 0.13 for math and reading, respectively. Thus, the marginal effect of the share of charter school enrollment starts to diminish when the percentage of students enrolled in charter school is about 12 percent for math and 13 percent for reading. The nonlinearity of the graphs in Figures 1 and 2 imply that different states experience different effects of charter competition depending on the percentage of students enrolled in charter schools in the states. To illustrate this, we provide the marginal effects of competition for a few selected states in Table 3. These states have different percentages of students enrolled in charter schools that may be of interest. Kentucky is one of the eight states in the nation that did not allow charter schools as of 2015. The percentage of students enrolled in charter schools is, therefore, zero. Oregon represents the mean of the percentage of students enrolled in charter schools in our dataset. District of Columbia has the highest percentage of students enrolled in charter schools. We also include our own state of Arkansas. 
Table 3: Marginal Effects for Selected States

\begin{tabular}{llll}
\hline \hline State & $\begin{array}{l}\text { Share of } \\
\text { Charter } \\
\text { Students }\end{array}$ & $\begin{array}{l}\text { Marginal } \\
\text { Effect } \\
\text { (Math) }\end{array}$ & $\begin{array}{l}\text { Marginal } \\
\text { Effect } \\
\text { (Reading) }\end{array}$ \\
\hline Kentucky & 0.000 & 1.691 & 1.487 \\
Arkansas & 0.026 & 1.811 & 1.582 \\
Oregon & 0.041 & 1.869 & 1.628 \\
$\begin{array}{l}\text { District of } \\
\text { Columbia }\end{array}$ & 0.394 & 0.760 & 0.907 \\
\hline \hline
\end{tabular}

Note 1: The share of charter school for each state is the average of the four years included in the panel dataset.

Table 3 shows that a 1 percentage-point increase in charter school enrollment in various states has different impacts. Take math for example. The marginal effect in Kentucky is 1.69 percentage points, while that of the District of Columbia is 0.76 percentage points. Similarly for reading, the marginal effect in Arkansas is 1.58 percentage points, while Oregon's is 1.63 percentage points.

For teacher freedom our results show that on average traditional public school students in states with charter school laws that allow teacher autonomy outperform those that do not. States that allow charter school teachers the choice to negotiate their contract work rules independently of the district and have a choice to participate in a retirement system (including the state's retirement system as an option), on average perform about 2 percent higher than those that do not in both math and reading (columns 10 and 12). Collective bargaining contracts contain provisions on how many classes teachers are required to teach, subjects and grade levels they are required to teach, how much preparation time as well as the frequency of meeting parents (Livingston, 2012). Such provisions can have an effect on the productivity of teachers which then affects the performance of students.

\section{Conclusion and Policy Recommendations}

Having a variety of alternatives injects competition into the education system and can affect performance similar to competition in other markets. As cited earlier, the evidence on the impact of charter schools is mixed, but mostly positive. Studies typically consider the number of students that are enrolled in charter schools as a measure of competition. Our study also considers teacher freedom as a competitive effect of charter schools on the public school system. Teachers may require a better environment in traditional public schools, and this can lead to better outcomes for their students.

Introduction of charter schools is not a be-all and end-all solution, but our study provides evidence that policymakers can take into consideration. We have shown that stronger charter schools' laws that encourage competition is associated with better student performance in reading. We also find that competition arising from flexibility in the organization and running of charter schools does not make states worse off in math. States legislatures can use our evidence in support of charter school laws to ensure better outcomes for students. Those states that do not have charter schools can consider injecting competition in their education system. 


\section{References}

Bohte, J. (2004). Examining the impact of charter schools on performance in traditional public schools. Policy Studies Journal, 32(4), 501-520.

Bifulco, R., \& Ladd, H. F. (2006). The impacts of charter schools on student achievement: evidence from North Carolina. Education Finance and Policy, 1(1), 50-90.

Booker, K., Gilpatric, S. M., Gronberg, T., \& Jansen, D. (2008). The effect of charter schools on traditional public school students in Texas: are children who stay behind left behind? Journal of Urban Economics, 64(1), 123-145.

Cordes, S. A. (2017). In pursuit of the common good: the spillover effects of charter schools on public school students in New York City. Education Finance and Policy, 1-49.

Davis, T. M. (2013). Charter school competition, organization, and achievement in traditional public schools. Education Policy Analysis Archives, 21, 88. doi:10.14507/epaa.v21n88.2013

Friedman, M., \& Friedman, R. (1990). Free to choose: A personal statement. Houghton Mifflin Harcourt.

Hsiao, C. (2007). Panel data analysis — advantages and challenges. Test, 16(1), 1-22.

Imberman, S. A. (2009). The effect of charter schools on achievement and behavior of public school students. SSRN Electronic Journal. doi:10.2139/ssrn.1031693

Jinnai, Y. (2014). Direct and indirect impact of charter schools' entry on traditional public schools: New evidence from North Carolina. Economics Letters, 124(3), 452-456.

National Alliance for Public Charter Schools. (2018). Charter law strength, Students in charter schools, Years existence. Retrieved from https://www.publiccharters.org/

National Center for Education Statistics (NCES) part of the U.S. Department of Education. (2018). Total enrollment, Expenditure Per Pupil, Free Reduced Lunch, Parent Teacher Ratio, English Language Proficiency. Retrieved from http://nces.ed.gov/

Papke, L. E., \& Wooldridge, J. M. (1996). Econometric methods for fractional response variables with an application to $401(\mathrm{k})$ plan participation rates. Journal of Applied Econometrics, 11(6), 619-632. 
Papke, L. E., \& Wooldridge, J. M. (2008). Panel data methods for fractional response variables with an application to test pass rates. Journal of Econometrics, 145(1-2), 121-133.

Sass, T. R. (2006). Charter schools and student achievement in Florida. Education

Finance and Policy, 1(1), 91-122.

U.S. Census Bureau. American FactFinder. Retrieved from https://factfinder.census.gov/faces/nav/jsf/pages/index.xhtml

Winters, M. A. (2012). Measuring the effect of charter schools on public school student achievement in an urban environment: Evidence from New York City. Economics of Education Review, 31(2), 293-301.

Wooldridge, J. M. (2015). Control function methods in applied econometrics. Journal of Human Resources, 50(2), 420-445.

Zgainer, A.C., \& Kerwin, K. (2015). Charter school laws across the States: 2015 Rankings and scorecard. The Center for Education Reform. Retrieved from https://edreform.com/wpcontent/uploads/2015/07/CharterLaws2015.pdf

Zimmer, R., \& Buddin, R. (2009). Is charter school competition in California improving the performance of traditional public schools? Public Administration Review, 69(5), 831845.

Zimmer, R., Gill, B., Booker, K., Lavertu, S., Sass, T. R., \& Witte, J. (2009). Charter schools in eight states: Effects on achievement, attainment, integration, and competition: Summary. Santa Monica, CA: RAND Corporation. 